\title{
Resistin, Is There any Role in the Mediation of Obesity, Insulin Resistance and Type-II Diabetes Mellitus?
}

\author{
Rajeev Pandey ${ }^{1 *}$ and Gurumurthy ${ }^{2}$ \\ ${ }^{1}$ Department of Biochemistry, Spartan Health Science University, West Indies \\ ${ }^{2}$ Department of Neurosciences, Spartan Health Science University, West Indies
}

Submission: February 21, 2018; Published: March 05, 2018

*Corresponding author: Rajeev Pandey, Department of Biochemistry, Spartan Health Science University, St. Lucia, West Indies, Email: rpandey@spartanmed.org

\begin{abstract}
Resistin is a member of a class of cystein-rich proteins collectively termed as resistin-like molecules. Resistin has been implicated in the pathogenesis of obesity-mediated insulin resistance and T2DM (Type II diabetes mellitus). In addition, resistin also appears to be a proinflammatory cytokine. Taken together, resistin, like many other adipocytokines, may possess a dual role in contributing to disease risk. However, to date there has been considerable controversy surrounding this $12.5 \mathrm{kDa}$ polypeptide in understanding its physiological relevance in both human and rodent systems. Furthermore, this has led question, whether resistin represents an important pathogenic factor in the etiology of T2DM or not. In this review, authors have made an attempt to discuss the key controversies and developments made so far towards the involvement of resistin molecule in the causation and progression of obesity and type II diabetes mellitus and factors associated with alteration in the expression of this magic molecule at physiological and genetic levels
\end{abstract}

Keywords: Resistin; Obesity; T2DM; Insulin resistance

\section{Introduction}

Adipose tissue is known to produce a vast array of adipocyte-derived factors, known as adipocytokines. Under normal physiological conditions adipocytokines may play an influential role in energy homoeostasis, triacylglycerol (triglyceride) storage and mobilization of fat, with increased adiposity, specifically central adiposity. These processes can be substantially dysregulated [1]. Furthermore, apparently the pathogenesis of T2DM (Type II diabetes mellitus) is mediated through the concurrent progression of insulin resistance and subclinical inflammation, although the molecular mechanisms for this are less understood. It is, however, apparent that obesity represents one of the foremost contributory factors leading to diabetes, as such; the expression and functional properties of adipocytokines and their effects on metabolism have been the subject of intense research. Indeed, studies on adipocytokines and their potential effects in human obesity and T2DM have implicated them in the pathogenesis of the metabolic syndrome. Such factors include TNF- $\alpha$ (tumour necrosis factor- $\alpha$ ), IL (interleukin)-6, angiotensinogen, leptin, PAI-1 (plasminogen activator inhibitor-1) and resistin. This review will address our current understanding of the pathophysiological role of resistin, and evaluate resistin as a pathogenic factor implicated in metabolic mechanisms leading to the development of T2DM. In addition, we will highlight the continuing complexity of the biology of resistin and its role in the progression of disease and the potential interplay between several mechanisms associated in the pathogenesis of T2DM.

Since the discovery of resistin in 2001, there have been over 260 publications that have informed our present understanding of its function. This has paradoxically created a maelstrom of controversy and ambiguity surrounding the functional significance of resistin. Indeed, researchers outside the field of resistin over the last few years have been unclear as to whether this molecule may deserve much attention as an important pathogenic factor in the progression of obesity-mediated diabetes. Nevertheless, although several questions remain unanswered to date regarding resistin, one question remains pertinent to all others, what is the precise physiological function of resistin? Although this is not necessarily an easy question to answer and this review may only highlight some aspects of resistin in disease, it is clear that the physiological role of resistin is more complex than originally envisioned. Despite an incomplete current understanding of the role of resistin, this review will assemble and discuss some of the existing literature 
on resistin evaluating the current metabolic effects of this protein, with the intent of providing an insight as to where the role of resistin may lie.

\section{The Discovery of Resistin}

Resistin, a putative adipocyte-derived signaling polypeptide, was originally identified by three independent groups using a variety of techniques [2,3]. Initial studies showed that resistin was up-regulated in rodent models of obesity and insulin resistance and down-regulated by an insulin-sensitizer, RSG (rosiglitazone) [3]; however, immunoneutralization of resistin reduced hyperglycemia and improved insulin sensitivity [3]. These observations not only brought resistin to much scientific attention, but characterized it as a potential etiological link between obesity and diabetes, with a clear functional role as a pathogenic factor contributing to insulin resistance. Additionally, this revealed possibilities of the mechanistic action for TZDs (thiozolidinediones) and their subsequent therapeutic applications.

\section{The Metabolic Role for Resistin: An Ongoing Debate \\ Resistin and obesity}

Since the initial investigation of resistin in numerous rodent models of obesity and insulin resistance [3,4], ongoing experimental data has generated further inconsistency. Human studies have highlighted increased resistin expression in adipose tissue [5], particularly abdominal depots [6,7]; furthermore, positive correlations between serum resistin and body fat content have also been reported [8]. On the contrary, several studies have failed to demonstrate such correlations in rodents, with groups also reporting either reduced [9-11] or no alteration [12] of resistin levels in various models of obesity. Although it is difficult to address such diverse findings using similar, and in some instances the same, rodent models, inconsistencies may depend upon methodological differences [13].

Studies by [14] showed that various murine models of obesity had higher circulating resistin levels compared with their lean counterparts. These observations coincided with rodent studies by Rajala and coworkers [15], showing circulating resistin levels significantly elevated and concordant with increasing levels of insulin, glucose and lipids; thus substantiating the initial evidence that addressed the etiology of resistin with increasing adiposity [3]. Recently, [16] determined that high-fat-fed mice had induced adipocyte differentiation, denoted by fatty acid binding protein (AP-2) gene expression, a surrogate marker of differentiation, which positively correlated with resistin gene expression. Subsequently, in view of this and previous studies [17], it was suggested that elevated resistin expression was a result of adipocyte differentiation [16]. Moreover, the increase in adipocyte number may have caused a rise in local resistin production, inhibiting insulin action on glucose uptake in adipose tissue and, thus, preventing further adipocyte differentiation [16]. Therefore, at least in rodents, a regulatory feedback mechanism for resistin in adipogenesis may occur, acting as an adipose sensor for nutritional status. In accordance with these observations, [18] generated transgenic mice over expressing a dominant inhibitory form of resistin which functioned to block the inhibition of resistin mediated adipocyte differentiation. These transgenic mice developed obesity, possibly owing to enhanced adipocyte differentiation and adipocyte hypertrophy, as indicated by increased circulating levels of adiponectin and leptin [18].

Recent investigations of human resistin in relation to obesity have shown higher serum resistin levels in obese subjects compared with lean subjects [19-21], which positively correlated with the changes in BMI (body mass index) and visceral fat area [21-23]. The implication that resistin is important in human adipose tissue has been corroborated by studies showing increased protein expression with obesity [23], as well as protein secretion from isolated adipocytes [24]. These recent observations are concomitant with initial studies that showed increased serum resistin levels [8] and gene expression levels in abdominal depots $[6,7]$ in states of increased adiposity. A further study has shown significant reduction in circulating resistin levels following moderate weight loss and post-gastric bypass [19]. Collectively, these observations suggest resistin could indirectly be subjected to nutritional regulation in humans.

\section{Resistin, insulin resistance and T2DM}

It is currently established that central obesity is a contributing factor to the pathogenesis of insulin resistance and consequently to T2DM. Although, it is apparent that inconsistencies remain in the data for a role of resistin in obesity, there is a growing body of evidence suggesting a role for resistin in the etiology of insulin resistance and T2DM.

In evaluating resistin and its association with insulin sensitivity in humans, several studies have identified positive correlations between resistin levels and insulin resistance in vivo [25] and in vitro [26]. Additionally, serum resistin levels were increased by approx. 20\% in T2DM subjects [24], such findings have been re-affirmed by [27]. In contrast, other studies have reported no associations between serum resistin levels and markers of insulin resistance in T2DM patients [28-30] or insulinresistant patients [31]. Moreover, serum and plasma resistin levels were either reduced or increased in T2DM patients with no significant correlation with HOMA-IR (homoeostasis model assessment for insulin resistance), waist circumference, BMI or total cholesterol $[32,33]$. Consequently, these studies suggest resistin is unlikely to play a critical endocrine role in insulin resistance or energy homoeostasis in humans. Nevertheless, a paracrine or autocrine manner of resistin to moderately affect metabolism cannot be ruled out.

\section{Human genetic studies of resistin}

Several SNPs (single nucleotide polymorphisms) have been identified in the Retn gene, but only few have minor allele 


\section{Juniper Online Journal of Case Studies}

frequencies over $5 \%$ and are associated with disease risk [3436]. Therefore further confusion ensues when reviewing genetic studies examining associations between resistin and disease. In a study of non-diabetic French Canadians in Quebec [34], two Retn 5'-flanking SNPs (-537 and -420) were associated with increased BMI. Furthermore, a resistin genotype at nucleotide +299 (IVS2 +181G $\rightarrow$ A) and obesity was a significant determinant of T2DM risk among Type II diabetic Caucasians in Boston (MA, U.S.A.) [37]. Additionally, the $-420 \mathrm{C} \rightarrow \mathrm{G}$ SNP ( -180 relative to putative transcription start site) was associated with higher resistin mRNA levels in abdominal fat of obese subjects [26]. Conversely, [35] showed an association between the $-420 \mathrm{C} \rightarrow \mathrm{G}$ polymorphism with lower BMI in non-diabetic individuals from a Brazilian population of European descent, although, among non-diabetic Caucasians in Sicily and Gargano (Italy), an ATG triplet repeat in the 3' -untranslated region of the resistin gene was associated with a decreased risk of insulin resistance [38].

Genetic analysis of resistin using a Japanese population demonstrated that a $-420 \mathrm{G} / \mathrm{G}$ genotype was associated with T2DM and could accelerate the onset of disease by 4.9 years [35]; moreover, the genotype itself was a primary variant determining T2DM susceptibility [36]. Consistent with these findings, elevated levels of serum resistin were reported in T2DM subjects carrying the $-420 \mathrm{G} / \mathrm{G}$ genotype [39]. In contrast, studies in a Japanese obese population reported $-638 \mathrm{G} \rightarrow \mathrm{A},-420 \mathrm{C} \rightarrow \mathrm{G}$, and $-358 \mathrm{G} \rightarrow$ A SNPs, which although associated with serum resistin, did not confer any association with obesity or insulin resistance $[40,41]$. These genetic studies highlight the discrepancies in resistin SNP analysis examining the association with obesity related insulin resistance; these may partly be explained by different genetic backgrounds or environmental conditions of the populations studied. So, further studies on the physiology of resistin and genetic implications for the development of this disease are therefore crucial.

\section{Conclusion}

Though, literature is full of studies supporting the correlation of resistin with obesity and insulin resistance in both clinical and experimental laboratory models, but at the same time, handful contradictory reports again forced to the scientists to look into the genetics and other triggering factors involved in the expression of resistin. So, these can be accounted prior to make any final recommendations on this magic molecule as an investigative/diagnostic tool for early detection of risk of two of the major health problems of the day i.e., obesity and type II diabetes mellitus.

\section{References}

1. Mohamed Ali V, Pinkney JH, Coppack SW (1998) Adipose tissue as an endocrine and paracrine organ. Int J Obes Relat Metab Disord 22(12): 1145-1158.

2. Holcomb IN, Kabakoff RC, Chan B, Baker TW, Gurney A, et al. (2000) FIZZ1, a novel cysteine-rich secreted protein associated with pulmonary inflammation, defines a new gene family. EMBO J 19(15): 4046-4055.
3. Steppan CM, Bailey ST, Bhat S, Brown EJ, Banerjee RR, et al. (2001) The hormone resistin links obesity to diabetes. Nature 409(6818): 307312 .

4. Levy JR, Davenport B, Clore JN, Stevens W (2002) Lipid metabolism and resistin gene expression in insulin-resistant Fischer 344 rats. Am J Physiol Endocrinol Metab 282(3): E626-E633.

5. Savage DB, Sewter CP, Klenk ES, Segal DG, Vidal-Puig A, et al. (2001) Resistin/Fizz3 expression in relation to obesity and peroxisome proliferator-activated receptor- $\gamma$ action in humans. Diabetes 50(10): 2199-2202.

6. McTernan CL, McTernan PG, Harte AL, Levick PL, Barnett AH, et al (2002) Resistin, central obesity, and type 2 diabetes. Lancet 359(9300): 46-47.

7. McTernan PG, McTernan CL, Chetty R, Jenner K, Fisher FM, et al. (2002) Increased resistin gene and protein expression in human abdominal adipose tissue. J Clin Endocrinol Metab 87(5): 2407.

8. Zhang J, Qin Y, Zheng X, Qiu J, Gong L, et al. (2002) The relationship between human serum resistin level and body fat content, plasma glucose as well as blood pressure. Zhonghua Yi Xue Za Zhi 82(23): $1609-1612$.

9. Way JM, Görgün CZ, Tong Q Uysal KT, Brown KK, et al. (2001) Adipose tissue resistin expression is severely suppressed in obesity and stimulated by peroxisome proliferator-activated receptor $\gamma$ agonists. J Biol Chem 276(28): 25651-25653.

10. Rajala MW, Lin Y, Ranalletta M, Yang XM, Qian H, et al. (2002) Cell typespecific expression and co regulation of murine resistin and resistinlike molecule- $\alpha$ in adipose tissue. Mol Endocrinol 16(8): 1920-1930.

11. Steppan CM, Lazar MA (2002) Resistin and obesity-associated insulin resistance. Trends Endocrinol Metab 13: 18-23.

12. Le Lay S, Boucher J, Rey A, Laurell IC, Krief S, et al. (2001) Decreased resistin expression in mice with different sensitivities to a high-fat diet. Biochem Biophys Res Commun 289(2): 564-567.

13. Fain JN, Cheema PS, Bahouth SW, Lloyd Hiler M (2003) Resistin release by human adipose tissue explants in primary culture. Biochem Biophys Res Commun 300(3): 674-678.

14. Lee JH, Bullen JW, Stoyneva VL, Mantzoros CS (2005) Circulating resistin in lean, obese and insulin-resistant mouse models: lack of association with insulinemia and glycemia. Am J Physiol Endocrinol Metab 288(3): E625-E632.

15. Rajala MW, Qi Y, Patel HR, Takahashi N, Banerjee R, et al. (2004) Regulation of resistin expression and circulating levels in obesity, diabetes, and fasting. Diabetes 53(7): 1671-1679.

16. Asensio C, Rose PC, Carrillo CT, Jeanrenaud FR, Muzzin P (2004) Changes in glycemia by leptin administration or high-fat feeding in rodent models of obesity/type 2 diabetes suggest a link between resistin expression and control of glucose homeostasis. Endocrinology 145(5): 2206-2213.

17. Haugen F, Jørgensen A, Drevon CA, Trayhurn P (2001) Inhibition by insulin of resistin gene expression in 3T3-L1 adipocytes. FEBS Lett 507(1): 105-108.

18. Kim KH, Zhao L, Moon Y, Kang C, Sul HS (2004) Dominant inhibitory adipocyte-specific secretory factor (ADSF)/resistin enhances adipogenesis and improves insulin sensitivity. Proc Natl Acad Sci U S A 101(17): 6780-6785

19. Vendrell J, Broch M, Vilarrasa N, Molina A, Gómez JM, et al. (2004). Resistin, adiponectin, ghrelin, leptin, and proinflammatory cytokines: relationships in obesity. Obes Res 12(6): 962-971.

20. Schäffler A, Büchler C, Ladner UM, Herfarth H, Ehling A, et al. (2004). Identification of variables influencing resistin serum levels in patients 
with type 1 and type 2 diabetes mellitus. Horm Metab Res 36(10): 702707.

21. Yamauchi MD, Bovenkerk JE, Juliar BE, Watson W, Kerr K, et al. (2003) Serum resistin (FIZZ3) protein is increased in obese humans. J Clin Endocrinol Metab 88(11): 5452-5455.

22. Azuma K, Katsukawa F, Oguchi S, Murata M, Yamazaki H, et al. (2003) Correlation between serum resistin level and adiposity in obese individuals. Obes Res 11(8): 997-1001.

23. Vozarova de Courten B, Yamauchi MD, Considine RV, Tataranni PA (2004) High serum resistin is associated with an increase in adiposity but not a worsening of insulin resistance in Pima Indians. Diabetes 53(5): 1279-1284.

24. McTernan PG, Fisher FM, Valsamakis G, Chetty R, Harte A, et al. (2003) Resistin and type 2 diabetes: regulation of resistin expression by insulin and rosiglitazone and the effects of recombinant resistin on lipid and glucose metabolism in human differentiated adipocytes. J Clin Endocrinol Metab 88(12): 6098-6106.

25. Silha JV, Krsek M, Skrha JV, Sucharda P, Nyomba BL, et al. (2003) Plasma resistin, adiponectin and leptin levels in lean and obese subjects: correlations with insulin resistance. Eur J Endocrinol 149: 331-335.

26. Smith SR, Bai F, Charbonneau C, Janderová L, Argyropoulos G (2003) A promoter genotype and oxidative stress potentially link resistin to human insulin resistance. Diabetes 52(7): 1611-1618.

27. Fujinami A, Obayashi H, Ohta K, Ichimura T, Nishimura M, et al. (2004) Enzyme-linked immunosorbent assay for circulating human resistin: resistin concentrations in normal subjects and patients with type 2 diabetes. Clin Chim Acta 339(1-2): 57-63.

28. Lee JH, Chan JL, Yiannakouris N, Kontogianni M, Estrada E,et al. (2003) Circulating resistin levels are not associated with obesity or insulin resistance in humans and are not regulated by fasting or leptin administration: cross-sectional and interventional studies in normal, insulin-resistant, and diabetic subjects. J Clin Endocrinol Metab 88(10): 4848-4856.

29. Pfützner A, Langenfeld M, Kunt T, Löbig M, Forst T (2003). Evaluation of human resistin assays with serum from patients with type 2 diabetes and different degrees of insulin resistance. Clin Lab 49(11-12): 571 576 .

30. Stejskal D, Adamovská S, Bartek J, Juráková R, Prosková J (2003) Resistin concentrations in persons with type 2 diabetes mellitus and in individuals with acute inflammatory disease. Biomed Pap Med Fac Univ Palacky Olomouc Czech Repub 147(1): 63-69.

31. Hegele RA, Kraw ME, Ban MR, Miskie BA, Huff MW, et al. (2003) Elevated serum $\mathrm{C}$-reactive protein and free fatty acids among nondiabetic carriers of missense mutations in the gene encoding lamin A/C (LMNA) with partial lipodystrophy. Arterioscler Thromb Vasc Biol 23(1): 111-116.

32. Youn BS, Yu KY, Park HJ, Lee NS, Min SS, et al. (2004) Plasma resistin concentrations measured by enzyme-linked immunosorbent assay using a newly developed monoclonal antibody are elevated in individuals with type 2 diabetes mellitus. J Clin Endocrinol Metab 89(1): 150-156

33. Yang J, Li M, Wu CY, Wang $\mathrm{H}, \mathrm{Xu}$ QS, et al. (2003) Reduced resistin levels in patients with type 2 diabetes mellitus. Zhonghua Yi Xue Za Zhi 83(17): 1471-1474.

34. Engert JC, Vohl MC, Williams SM, Lepage P, Osti JCL, et al. (2002) 5' flanking variants of resistin are associated with obesity. Diabetes 51(5): 1629-1634.

35. Mattevi VS, Zembrzuski VM, Hutz MH (2004) A resistin gene polymorphism is associated with body mass index in women. Hum Genet 115(3): 208-212.

36. Osawa H, Yamada K, Onuma H, Murakami A, Ochi M, et al. (2004) The $\mathrm{G} / \mathrm{G}$ genotype of a resistin single-nucleotide polymorphism at -420 increases type 2 diabetes mellitus susceptibility by inducing promoter activity through specific binding of Sp1/3. Am J Hum Genet 75(4): 678686.

37. Ma X, Warram JH, Trischitta V, Doria A (2002) Genetic variants at the resistin locus and risk of type 2 diabetes in Caucasians. J. Clin Endocrinol Metab 87(9): 4407-4410.

38. Pizzuti A, Argiolas A, Di Paola R, Baratta R, Rauseo A, et al. (2002)An ATG repeat in the 3'untranslated region of the human resistin gene is associated with a decreased risk of insulin resistance. J Clin Endocrinol Metab 87(9): 4403-4406.

39. Azuma K, Oguchi S, Matsubara Y, Mamizuka T, Murata M, et al. (2004) Novel resistin promoter polymorphisms: association with serum resistin level in Japanese obese individuals. Horm Metab Res 36(8): 564-570.

40. Osawa H, Onuma H, Murakami A, Ochi M, Nishimiya T, et al. (2002) Systematic search for single nucleotide polymorphisms in the resistin gene: the absence of evidence for the association of three identified single nucleotide polymorphisms with Japanese type 2 diabetes. Diabetes 51(3): 863-866.

41. Ochi M, Osawa H, Onuma H, Murakami A, Nishimiya T,et al. (2003) The absence of evidence for major effects of the frequent SNP +299G $>$ A in the resistin gene on susceptibility to insulin resistance syndrome associated with Japanese type 2 diabetes. Diabetes Res Clin Pract 61(3): 191-198. 